\title{
FEASIBILITY DEMONSTRATION OF TECHNOLOGIES FOR THE DEVELOPMENT OF PINE BURNT WOODS WITH THE AIM OF REESTABLISHMENT OF THE PINE STAND FROM THE SEEDS REMAINING IN TREE CROWNS AFTER A LOW FIRE
}

\author{
Yuri Shirnin* \\ Volga State University of Technology, Yoshkar-Ola,Russia \\ Sergey Denisov \\ Volga State University of Technology, Yoshkar-Ola,Russia \\ Aleksandr Shirnin \\ Volga State University of Technology, Yoshkar-Ola, Russia
}

The following research deals with the issues of technologies of reforestation development of burnt pine trees stands. Middle-aged, ripening and mature pine stands, damaged by creeping fire, keep a stock of germinating seeds. The amount of pine seeds is sufficient for natural development of deciduous-pine growths under such conditions. A variety of machine systems and technologies are provided in order to secure available seed stock during the process of logging marketable timber within burnt wood stand areas. Moreover, these systems would facilitate felling areas of burnt wood with advance growth.

Key words: Pine wood, Forest fires, Burnt timber, Reforestation methods, Machine systems, Burnt timber development technology

\section{INTRODUCTION}

A strong fire danger in pine woods, which are spread on the sandy left bank lowland of the Volga paves the way for regular major forest fires within approximate intervals of $30-50$ years [05, $06,12,13,27,28]$. These fires lead to the deprivation of forest stand growing power on large territories. Timber volume in burnt forest stands of 1972 were evaluated in 1994 as 20 million m3 [04]. After the fires in 1972 it reduced to 11.8 million $\mathrm{m} 3$. As a consequence of fires in 2010, over 76.5 thousand hectares [28], timber stands, according estimates, was around 6 million $\mathrm{m}^{3}$.

A stoppage for one or two years in felling of drying out pine stands after the fires results in loss of timber quality, as it decreases its grade and causes measurable losses. Considerable problems exist concerning pest insects expansion $[02,04,29]$. For this reason, logging in drying out forest stands should be held within the shortest possible period, following the conclusion of forest pathology inspection on the necessity of either clean or selective felling.
However, an urgent felling of ripening and middle-aged drying out forest stands causes complete demolition of viable seeds, remained in the crowns after creeping fires, if this felling is accomplished before June of the year following the fire. The seeds are destroyed during the felling of drying out and dry trees when the cutover patches are cleared [03, 09]. The absence of pine seeds within these territories necessitates creating large areas of forest plantations. The costs for these actions come out at tens million of rubles from the budget. For instance, "324.1 million rubles was given from the federal funds for post-disaster recovery, resulted from forest fires in $\mathbf{2 0 1 0}$ on the territory of Privolzhsky Federal district (for burnt wood clearing and preparing parcels for forest plantations" [15].

In the course of evolution, the pine has adapted to fire as for ecological factor [17, 18], thus it provides its domination on sandy soil. Accordingly, flame soil cultivation facilitates natural pine restoration and should be considered as one of most effective and economic actions for forest regeneration. Preservation of seeds, during the 
development of marketable burnt wood which emerged from creeping fires, is currently important in order to rescue local pines. Moreover, it would reduce the expenses for artificial forest regeneration significantly.

Silvicultural prerequisites for the selection of machine systems and technologies were based on the results of deep research in newly grown pine woods of Mari El, Russia, on the territories which had suffered from the low fire. Thorough and detailed study of these areas was carried out between 2010 and 2015 .

The aim of the paper is substantiation of machine systems and appropriate technologies for development of marketable burnt timber, fitted to natural pine trees regeneration within the areas, damaged by fire.

Objectives:

1) to determine the potential capacity for natural reestablishment of forest on the large burnt areas;

2) to substantiate the selection of machine systems and process diagrams for the development of marketable burnt timber in order to provide positive conditions for natural pine trees reproduction;

3 ) to accomplish planning compartments within the territories, damaged by fire, with presence of marketable burnt timber.

Subjects and methods of the research.

The subjects of the given research are burnt timbers of pine forest stands on the territories of large fires in Mari El, Russia, more specifically, within the wood area of Kuyar district forestry, damaged by low forest fires.

The methods, selected for the following study include field investigations of the quantity of viable seed material of tree species within the area damaged by a fire. For this purpose, the seed material of tree species was couched in a laboratory environment. The soil salvages had been taken from burnt timber areas. Additionally, during the research, there was determined the amount of viable pine seeds remaining in tree crowns two months after the fires had stopped.

Circular discount areas, approximately $10 \mathrm{~m}^{2}$ in size, were located over a distance of 20 meters from each other within 5 transects. The length of each transect was 200 meters. Ten soil samples, not less than $5 \mathrm{~cm}$ deep were taken from every discount area. As the result, 500 samples were involved into seed material couching.
Within the bounds of the research, the burnt timber on the first transect was cut down during the first two months after the fires of 2010. In the summer 2011, the area of burnt timber was cut down on the transect №5. The rest transects appeared to be under the cover of failed forest stands.

In the autumn 2010, after the development of the burnt wood on the first transect, conelets were gathered from the ground and from the live branches of the slash. The seeds, taken out of them were couched in laboratory environment. The field studies of tree species natural reestablishment were continued in 2011.

\section{RESULTS}

Laboratory studies have shown significant initial forest coverage of the burnt wood with birch trees. Its abundance of sprouts reaches tens millions per hectare. The energy level of pine seeds sprouting, drawn out of the cones, which had been gathered from the ground, made up $20 \%$, while those, taken of the cones gathered from slash equaled $58 \%$. The results of field registrations of young seedlings in summer 2011 have demonstrated that species composition is mostly represented with pine trees and aspens. Birch trees are found less frequently, as its seeds lost their germinating ability during winter and spring periods. The amount of pine sprouts is considerably larger on undeveloped burnt forest areas, than on the territories, where timber stand has been developed.

According to observation data, pine sprouts were not detected on the first transect where burnt wood was cut down in autumn. Sprouts on the discount areas are represented by aspen (0-2 million $\mathrm{u} / \mathrm{ha}$ ) and by less number of birch. At the same time, transects №2-4, hidden under failed forest stands coverage, show pine sprouts, which occupy nearly half of the whole amount of all sprouts. Their density on discount areas fluctuates from 100 to 225 thousand $\mathrm{u} / \mathrm{ha}$. As for birch sprouts, their number varies from 8 to 100 , though aspen represents from 70 to 350 thousand $u / h a$. Consequently, pine may occupy about $50 \%$ in the composition of future young regeneration. The first results, achieved in a year after the fires, verify that the number of birch sprouts on the burnt areas is significantly smaller than efficiency of laboratory investigations of seed material. The amount of pine sprouts within 
burnt areas, containing live tree crowns is considered to be sufficient for successful natural pine wood reestablishment.

\section{DISCUSSION}

In the first place, pine crowns possessed a great number of viable seeds with germinative power around $80 \%$ in the areas of creeping fires, after large fires in 2010 [14]. An amount of viable seeds was equal to 500 thousand per hectare. This fact corresponds to an average seed crop in pine woods and the quantity of seeds is quite sufficient for successful natural pine regeneration within burnt areas. However, burnt wood, developed before May of the year following the fire, are not regenerated by pine trees substantially. This resulted from destroying seeds during clearance of wood fellings, as wood growers pointed out, while they investigated forest regeneration on major burnt areas after the fires of 1921 and 1972 [10, 16]. This silvicultural-technological mistake should be corrected, and the way out is to leave parts of crowns, which contain pine cones with seeds, while felling in fresh pine woods. Secondly, it is necessary to reserve new shootings, using the technologies of felling with preserving undergrowth on the timber stands territories, damaged by fire, on the year following the fire. Inspection of forest reproduction on burnt areas has shown that the quantity of two-year old pines on the territories damaged by fire in subors conditions varies from 8.1 to 35.4 thousand $\mathrm{u} / \mathrm{ha}-1$. At the same time, the amount of deciduous trees is tens, and in some places even hundreds times, greater than of pine trees. Early environmental cuttings may help to adjust young growth constitution, providing pine trees with challenge during the first step of underbrush formation. Birch and aspen would supplement the soil with litterfall, but yield precedence to pine trees [30]. Though, an intensive birch growth in the subors leads quickly to the pine oppression. In this case, cleaning would be needed on the fifth or seventh year following the fire [07].

It could be expected that there would be no need in environmental cuttings of the composition, as birch and aspen would not compete strongly with the pine, under the conditions of poor sand soils suffering from lack of moisture. The development of marketable burnt timber with some separate living pine trees should be conducted according technologies of conserving new growth. This conception would allow to preserve new sprouts between skidding trails.

The researches analysis [03, 08, 09, 18, 19, 22] revealed that natural reestablishment of pine trees within the territories damaged by a fire could be carried out only under certain conditions, which follow:

First, leave crowns with cones at the parcels of cutting, spreading them carefully and smoothly within the felling territory. That should be done in the process cutting the branches, after tree felling during the timber harvesting.

Second, pine sprouts and undergrowths should be preserved if a burnt wood development is carried out on the second year after the fire.

Third, clumps of standing up trees should be left for 3-4 years as seed material in order to increase the amount of undergrowth on the burnt areas.

Forth, early environmental cuttings are necessary in subors for the purpose of providing pine trees with competitive advantage during the first step of young stock formation.

For fire damaged wood harvesting it is essential to choose such machine systems and process diagrams, which could promote natural pine trees regeneration. Machine systems, including feller-delimber-bunchers (harvesters), concentrate cut branches either on the skidding track or near it. For that reason, they are not able to provide their equal smooth spreading on the given territory [21]. Consequently, it is no use to wait for equable sprouts of pine after harvester employment.

Machine systems and technologies of timber harvesting. At the heart of selection of machine systems and technology of timber harvesting within the fire damaged area lays integrated timber haulage, which features availability of both cable and tractor skidding in one technological operation [23].

Machine system №1 (Figure 1, a) consists of power saws ( 1 - for trees felling; 2 - for branch cutting, 4 - for timber bucking), and of energy and process modules. The machine is equipped with a winch for skidding tree-length logs and a load box for skidding timber assortments. 

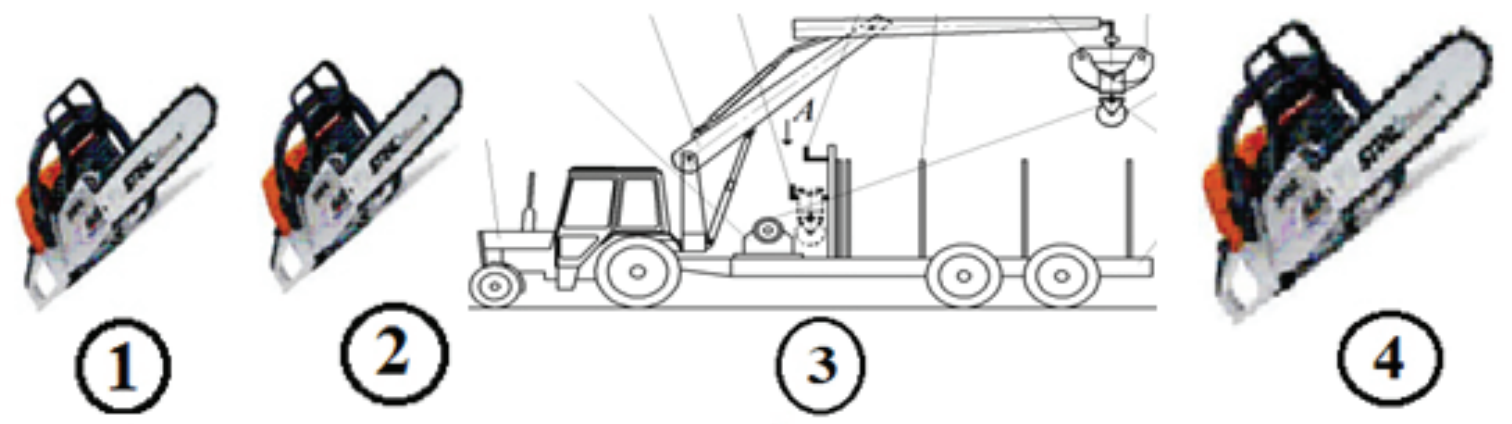

a)

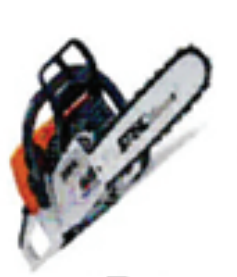

(1)
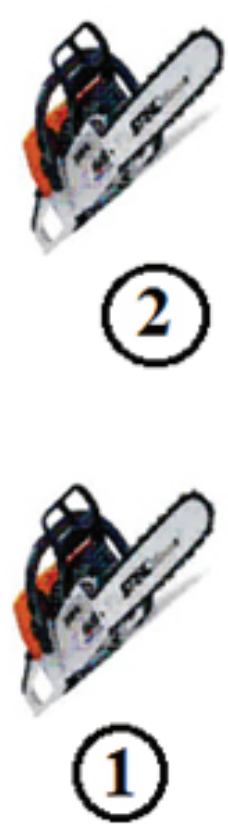

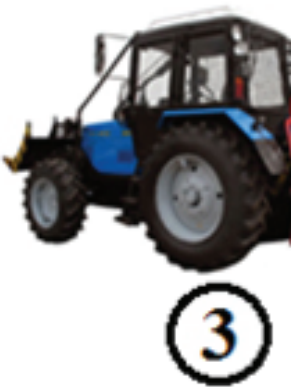

(3)
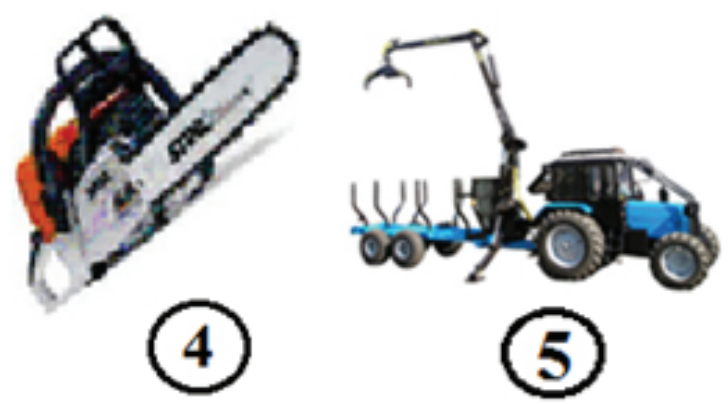

b)
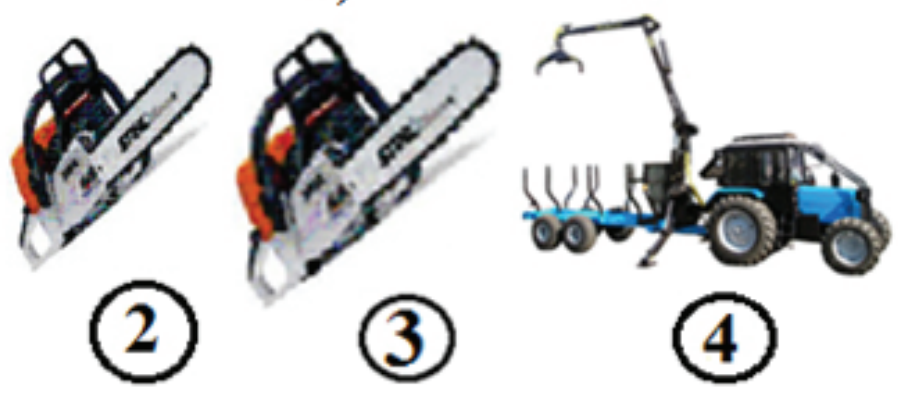

c)

Figure 1: Machine system for development of marketable burnt wood with reservation of forest regeneration potential

Machine system №2 (Figure 1b) consists of with cable-choker equipment (3 - «TTP-401Mpower saws ( 1 - for trees felling; 2 - for branch $\quad 02 »-$ for skidding tree-length logs), forwarder ( 5 cutting, 4 - for timber bucking), skidding tractor - MПT-461.1 - for skidding timber assortments.

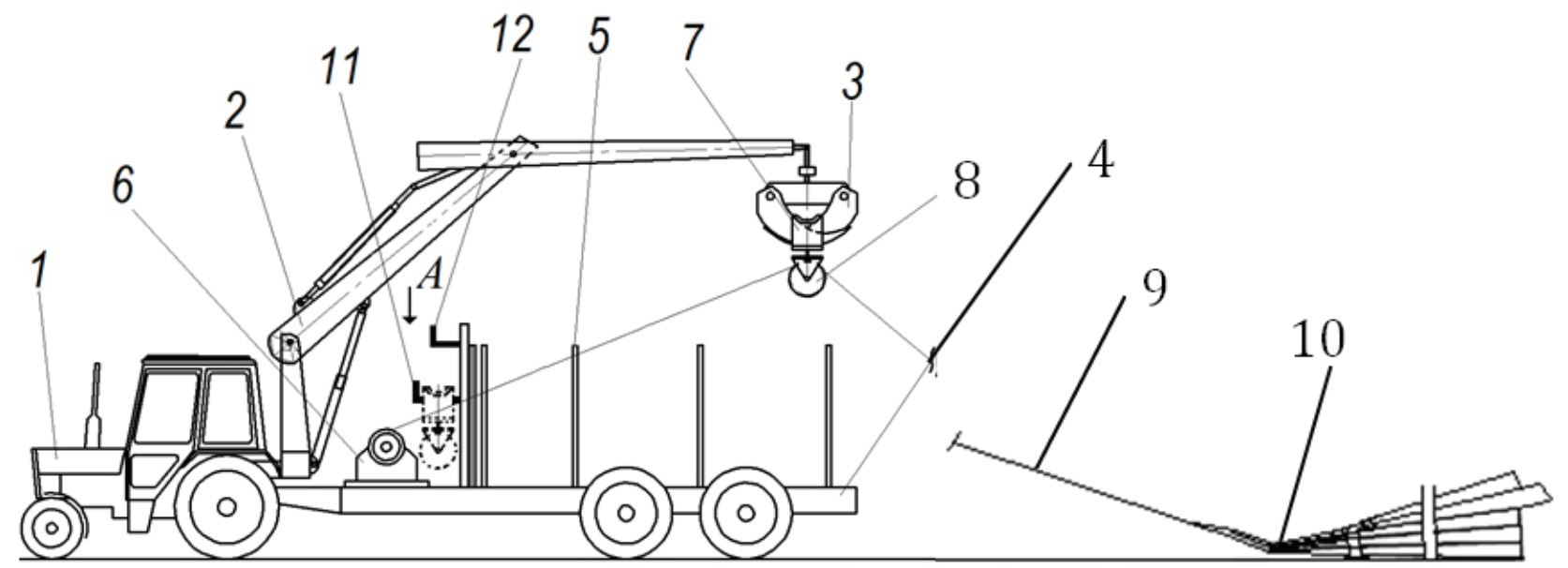

Figure 2: Machine for combined timber skidding 
Machine system №3 (Figure 1c) consists of (1 - for trees felling; 2 - for branch cutting, 4 - for timber bucking) and a forwarder (4 - МПТ-461.1 - for skidding timber assortments).

System №1 is formed on the base on machine for combined timber skidding [08, 20, 24, 25, 26]. A power module 1 (Figure 2) with a manipulator 2 with a clam at its end 3 is joined to a process module 4 with a load box 5 , winch 6 (for carrying out the first stage of skidding) device 7 for fixing foot block 8 (Figure 2) and chokers necessary for the period when the machine carries out the second stage of skidding.

Machine for combined skidding 2 (Figure 3 ) is mounted on principal logway or on compartment line 1. Its back part is directed to developing trail with borders 9 . The work is carried out in the following way. A chokerman takes chokers off hooks 12 and device 7 for foot block fixing 8 is taken off hooks 11 . After doing this, operator guides manipulator 2, grasps foot block foxing device, through which a load-carrying cable 9 is overleapt, by means of a clam, and raises it on a height, necessary for carrying out skidding with raised front end of tree loads. When a winch is disengaged, chokers, together with the end of a load-carrying cable, go down onto the ground surface under their own weight and then a chokerman separate them on longitudinal axis of the trail to the place of tree load forming. Lopping-off of cut down trees 7 is performed by means of power engine saws. Chokers 10 choke tree-length logs. A process module winch is engaged for winding load-carrying cable, tree-length logs are formed into bunches and hauled to principal logway 1 (first stage of skidding), where they are unhooked. Storage pile 4 is formed for further processing. Subsequently, the cycle is repeated till all minor bunches would be hauled to the principal logway from the trail. Timber harvesting machine moves onto another trail and skidding cycle is repeated in the way it has been already described. After performing on all trails, operator lowers the clam by means of manipulator, releases foot block fixing device when he opens the clam. Then, chokerman and operator put the hold for foot block and choker on corresponding hooks. At this, the machine is ready for skidding timber assortments.

When machine systems №1 operate (Figure 3 ), first of all, tree felling on the skidding trail is performed by means of gasoline-power saws. If skidding is done top end first, tree felling begins from the end of the skidding trail, which adjoins timber transport road or principal logway. Felling direction is carried out by adjoining tree tops to route-line of guy gathering cable 5 . If skidding is performed butt end first, tree felling starts from farther end of skidding trail in relation to principal logway. Tree felling direction in this case is parallel to the route-line of gathering cable. At this, the skidding trail is wider at skidding is done top end first because of top approximation to the routeline of gathering cable. Then, branch cutting is carried out by means of power saws and their equal distribution (position 8) within the territory of skidding trail. This helps to provide further areally uniform natural pine reproduction. Tree felling and branch cutting should be performed in advance of skidding in order to ensure work safety. After felling and cutting are completed, tree-length logs 7 , grubbed out by chokers 6 , are skidded with the help of a winch to principal logway 1. Then, timber bucking and assortment stacking 3 take place. When machine systems develop fire damaged timber stands (Figure 1, a) the first stage of skidding is carried out by a winch towards principal logway by means of combined skidding machine. The second stage of skidding towards timber transport road is performed by means of manipulator with a grapple and load box.

During this time, tree-length logs are cross-cut by gasoline saws in accordance with technological process. After cross-cutting of skidded treelength logs from the trails, which link to the principal logway, the machine perform assortment loading by means of clamp-hook into the load box of process module. Then, they are skidded onto the upper storage or to the hot deck, located near timber transport road.

Skidding trails development with machine system №2 is distinctive in the fact that after tree felling and branches cutting by means of power saw, extraction tractor drives onto the skidding trail. Following the choking, tree-length logs are skidded towards principal logway, where they are cross-cut. An assortment skidding, along the principal logway, is carried out by a forwarder.

In the machine system №3 tree-length logs cross-cutting is performed simultaneously with tree felling and branch cutting at a stump. Assortment skidding to timber transport road is accomplished by a forwarder. The forwarder drives on to the trail for gathering and loading assortments. 


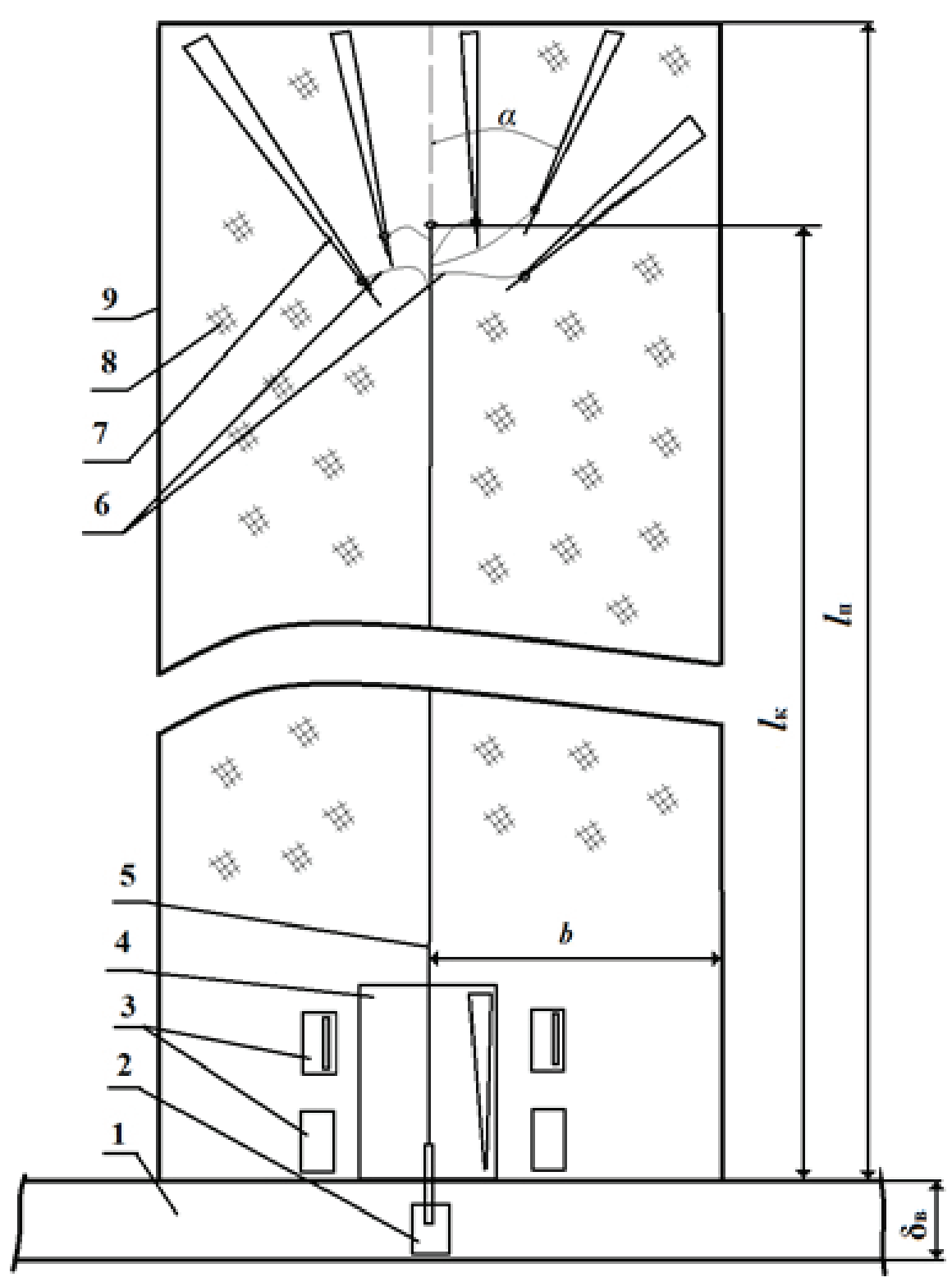

Figure 3. Diagram of skidding trail development: 1 - principal logway, 2 - combined skidding machine, 3 - assortment storage pile, 4 - tree-length log storage pile, 5 - load cable, 6 - chokers, 7 - tree-length log, 8 - branches, 9 - skidding trail boundaries

Planning compartment on the fire damaged territories, containing marketable burnt timber. The areas of major fires usually cover many compartments. Reasoning from this fact, preparatory and main actions should be planned in a different way. The boundaries of the fire-damaged areas can't be designed, that is why the concept 'logged land' loses its sense. At the basis of cutting area operations should be put a developing parcels tendency to approach passable compartment lines and existing roads for timber transportation. In this connection, the location of primary compartment net should be thought out carefully. On the one hand, it is necessary to cover the whole territory with trails net; on the other hand, it is important to provide minimum average skidding distance, minimal skidding trail, taking into consideration further natural regeneration. Possible planning map is represented on Figure 4. Compartment planning may be carried out in different ways depending on whether the number of section lines, bounding the compartment, suitable for timber transporting. Figure $4 \mathrm{a}$ demonstrates compartment with one road only; figure $4 \mathrm{~b}$ shows compartment with two roads. When the whole compartment is developed by machine system №1, the distance between principal logways would be longer than a double length (fig.3, to the left and to the right of the trail) of cable ranging. Developing plan of 
fire-damaged forest compartments is the following:

1) specification of forest roads, compartment lines, suitable for timber transportation (in the process of preliminary works);

2) compartment territory planning: arrangement of loading points, principal logways, road adjacent zones, road remote zones, skidding trails;

3) skidding trails development in zone 1, adjacent to timber transportation road;

4) furnishing and cutting of principal logways, passing through zone 1 and zone 2;

5) skidding trails development, adjacent to principal logways in zones 2.

Forest ecological functions damage rate can be evaluated with ecological coefficient $X[20,24]$, representing relation of compartment area designed for loading points, trails and technological corridors, to the whole compartment area. Taking into account that loading assortments onto the log trucks is carried out on the section lines, where there is enough space for staple, areas, occupied with loading points are not taken into consideration when calculating ecological coefficient:

$$
X=S_{p r} / S
$$

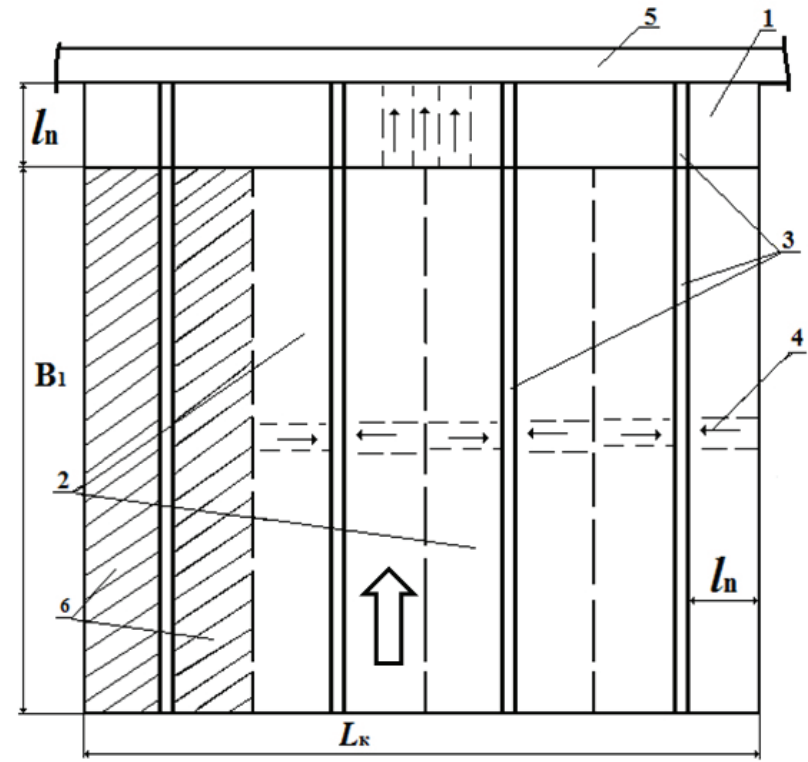

where $S_{p r}$ - compartment area, fitted for principal logways and skidding trails, $\mathrm{m}^{2}$; $\mathrm{S}$ - compartment area, $\mathrm{m}^{2}$.

The equations for calculating ecological coefficient were obtained by means of algebraic analysis. Thus, ecological coefficient for machine system № ${ }_{1}$ is:

$$
\chi_{1,2}=\frac{\frac{L_{\mathrm{K}}^{2} \cdot \delta_{\mathrm{B}}}{2 \cdot\left(l_{\mathrm{K}}+l_{\mathrm{X}} \cdot \cos \alpha\right)+\delta_{\mathrm{B}}}}{L_{\mathrm{K}} \cdot B_{\mathrm{K}}},
$$

where LK - compartment length, m; Bк - compartment width, $m ; \delta_{B}-$ width of principal logway, $\mathrm{m}$; I - length of hauling of the gathering cable, at which skidding is accomplished with a raised front end of skidding bunch, $\mathrm{m}[07,08]$; Ix - average length of stem, $m ; \alpha$ - angle, at which a tree fallen at a skidding trail boundary lies near the line of gathering cable, degrees.

Ecological coefficient for machine system №2 and №3 is:

$\chi_{\Pi 1}=\frac{\frac{L_{\mathrm{K}}^{2} \cdot \delta_{\mathrm{B}}}{2 \cdot l_{\Pi}+\delta_{\mathrm{B}}}+\left(\frac{B_{\mathrm{K}}-l_{\Pi}}{2 \cdot\left(l_{\mathrm{X}} \cdot \sin \alpha+c\right)} \cdot \frac{L_{\mathrm{K}}}{2 \cdot l_{\Pi}+\delta_{\mathrm{B}}}+\frac{L_{\mathrm{K}}}{2 \cdot\left(l_{\mathrm{X}} \cdot \sin \alpha+c\right)}\right) \cdot \rho \cdot l_{\mathrm{K}}}{L_{\mathrm{K}} \cdot B_{\mathrm{K}}}$

\section{for trailing to one section line}

where $\rho$ - length of skidding trails, $\mathrm{m}$; $\mathrm{c}$ - choker length excluding a binder loop, $\mathrm{m}$; In - length of a skidding trail, $\mathrm{m}$.

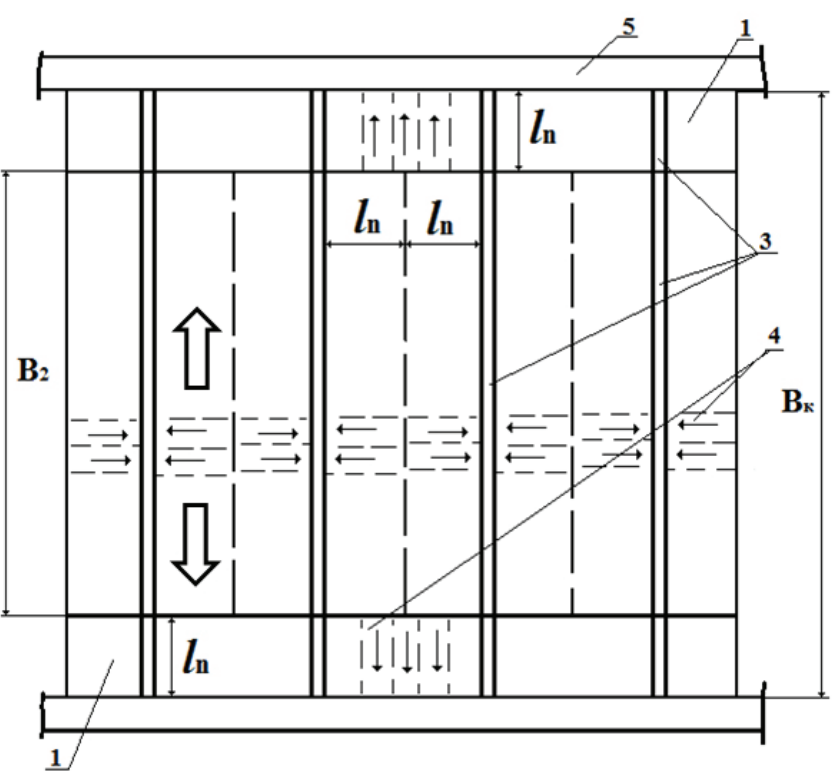

Figure 4: Compartment planning map: a - one section line suitable for logging, 1 - timber transportation road adjacent zone, 2 - zone, remote from timber transportation road, on which provided for combined skidding; 3 - principal logway; 4 - skidding trails; 5 - timber transportation road or section line, adapted for timber transportation; 6 - forest site area, close to principal logway; $\longrightarrow$ - cable skidding direction (first step); $\Rightarrow$ - assortment skidding direction (second step) 


\section{for trailing to two section lines}

$\chi_{\Pi 2}=\frac{\frac{L_{\mathrm{K}}^{2} \cdot \delta_{\mathrm{B}}}{2 \cdot l_{\Pi}+\delta_{\mathrm{B}}}+\left(\frac{B_{\mathrm{K}}-2 \cdot l_{\Pi}}{2 \cdot\left(l_{\mathrm{X}} \cdot \sin \alpha+c\right)} \cdot \frac{L_{\mathrm{K}}}{2 \cdot l_{\Pi}+\delta_{\mathrm{B}}}+\frac{2 \cdot L_{\mathrm{K}}}{2 \cdot\left(l_{\mathrm{X}} \cdot \sin \alpha+c\right)}\right) \cdot \rho \cdot l_{\mathrm{K}}}{L_{\mathrm{K}} \cdot B_{\mathrm{K}}}$

Variation of ecological coefficient with the length of gathering cable ranging on the skidding trail for machine system №1 during its work according to maps on Figure 4, calculated by formulas

$\chi$

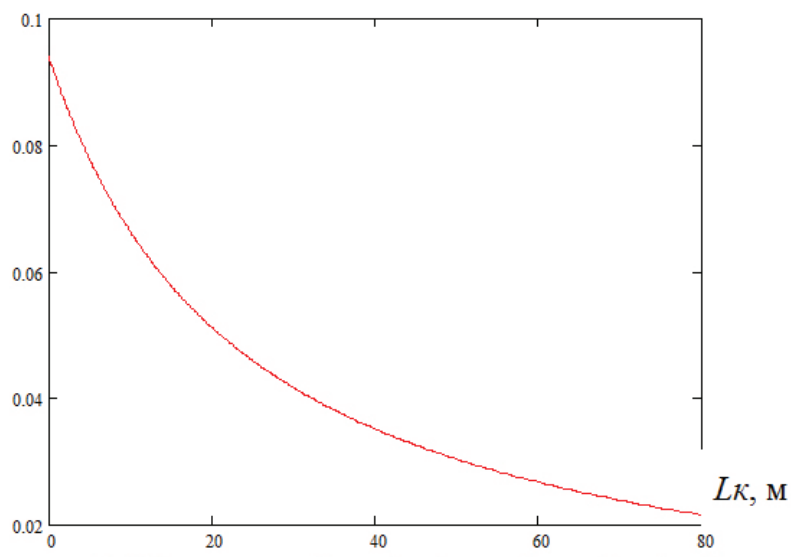

(2) is represented on picture 5a. Initial data: LK $=$ $1000 \mathrm{~m}, \mathrm{BK}=1000 \mathrm{~m}, \delta \mathrm{B}=4,5 \mathrm{~m}, \mathrm{Ix}=25 \mathrm{~m}$.

Variation of ecological coefficient with skidding trail length for machine system №2, 3 during its work according to maps on Figure 4, calculated by formulas $(3,4)$ is represented on picture $5 b$. Initial data: $\mathrm{L \kappa}=1000 \mathrm{~m}, \mathrm{B \kappa}=1000 \mathrm{~m}, \delta \mathrm{B}=4,5 \mathrm{~m}$, $\mathrm{Ix}=25 \mathrm{~m}, \mathrm{c}=2 \mathrm{~m}, \rho=3 \mathrm{~m}$.

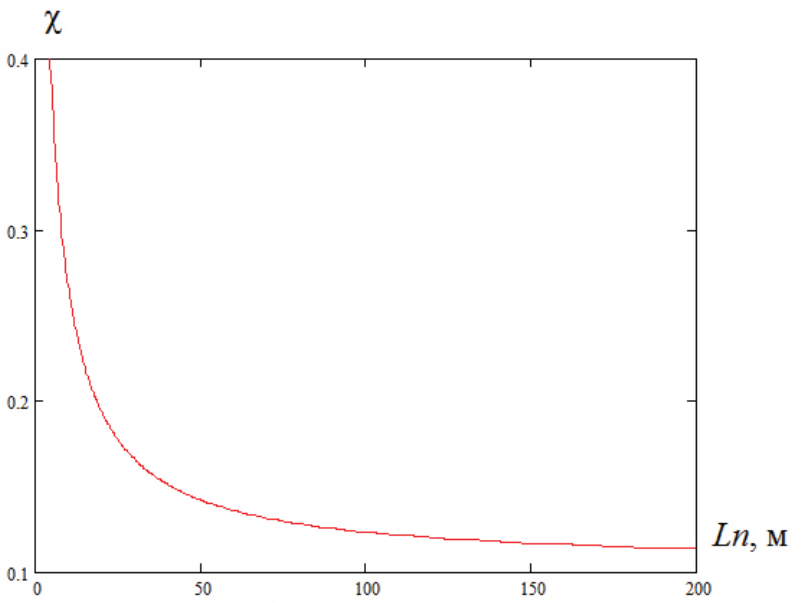

Figure 5: Diagram of variation of ecological coefficient: a - with the length of gathering cable ranging on the skidding trail for machine system №1; $b$ - with skidding trail length for machine system №2, 3

\section{CONCLUSIONS}

1. After creeping fires, there is a significant amount of viable seeds in the crowns of dead seed-bearing pines sufficient for effective natural pine regeneration. An urgent cut down of pine wood stands, damaged by fire, and further clearance leads to complications with natural reestablishment of pines within burnt areas.

2. In order to keep local pine trees population after creeping fires, it should be efficient to develop forest stands damaged by a fire using technologies, which would help to preserve pine seed material for natural reestablishment.

3. A technology, providing a more equal distribution of small and big branches from cut tree crowns would achieve a larger spreading of viable seeds within the developing area, as contrasted with machine harvesting, logging and branch cutting by means of power saws.

4. It would be appropriate to use existing roads and section lines in order to transport timber from fire-damaged territories. Planning maps are recommended for greater fire-damaged areas, in reliance to a variety of possible options for timber transportation roads arrangement.

5. Technology of combined skidding is proposed for minimizing the area of developed territories from machine activity. It would provide timber harvesting and save a considerable area for natural pine regeneration without laying skidding trails.

6. Diagram on Figure 5 shows that ecological coefficient for machine system №1 changes within the range of $0.02-0.06$. It means that only from $2 \%$ to $6 \%$ of the territory would be affected by trails. For machine system №2 and №3 about 15\%-25\% would be under the trails, if the skidding is carried out to one or two section lines.

7. Suggested variants of marketable burnt stand development provides an opportunity to preserve local pine trees population on account of using seed stock in the crowns of burnt timber stands and to reduce expenditure on artificial forest regeneration. 


\section{REFERENCES}

1) Anan'ev V.A. et al., (2005). Intermediate forest in northwest Russia. Joensuu: Finnish Forest Research Institute.

2) Averkiev, I.S. (1976). Zarazhennost gorelnikov entomovreditelyami $v$ lesakh Mariyskoy ASSR i mery bor-by s nimi. U Problemy likvidatsii posledstviy lesnykh pozharov 1972 g. v Mariyskoy ASSR. (str. 86-93). YoshkarOla: MarPI.

3) Chistyakov A.R., (1976). Estestvennoe vozobnovlenie $\mathrm{v}$ raznykh tipakh garey. U Problemy likvidatsii posledstviy lesnykh pozharov 1972 g. v Mariyskoy ASSR. (str. 68-75). Yoshkar-Ola: MarPI

4) Demakov, Y.P. (2007). Postpirogennaya dinamika ksilofilnogo entomokompleksa v sosnovykh lesakh Mariyskogo polesya. Nauchnye trudy zapovednika «Bolshaya Kokshaga», 2, 248-302.

5) Denisov, A.K. (1978). Lesnye pozhary v Mariyskoy ASSR i Gorkovskom Zavolzhe. U: Gorenie i pozhary v lesu. Tez. dokladov i soobshcheniy 1-go vsesoyuznogo nauch.tekhn. soveshchaniya, Krasnoyarsk. 38-40.

6) Denisov, A.K. (1978). Lesnye pozhary $\vee$ lesnom srednem Zavolzhe v 1921 i 1972 gg. i ikh uroki. U: Gorenie i pozhary v lesu. Tez. dokladov i soobshcheniy 1-go vsesoyuznogo nauch.tekhn. soveshchaniya, Krasnoyarsk. 16-26.

7) Denisov A.K., (1954). Formirovanie smeshannykh drevostoev na svezhikh garyakh. Forestry, 10, 26-31.

8) Denisov, S.A. (1979). Regulirovanie roli berezy v estestvennom vozobnovlenii garey. Forestry, 7, 19-21.

9) Denisov S.A., (2015). Upravlenie lesovosstanovleniem na garyakh. Vestnik of Volga State University of Technology. Series: Forest. Ecology. Nature management, 27(3), 5-15.

10) Denisov S.A., (2011). Prognozirovanie lesovozobnovleniya na svezhikh sosnovykh goreInikakh. U: Lesnye ekosistemy v usloviyakh izmeneniya klimata, Yoshkar-Ola. 181-183.

11) Dvoretskiy, M.L. (1976). Vliyanie pozharov 1972 goda na tovarnuyu strukturu sosnovogo drevostoya i nekotorye fiziko-mekhanicheskie kachestva drevesiny sosny. U Problemy likvidatsii posledstviy lesnykh pozharov 1972 g. v Mariyskoy ASSR. (str. 110-
113). Yoshkar-Ola: MarPI.

12) Kalinin, K.K. (2012). Krupnye lesnye pozhary $v$ lesnom srednem Zavolzhe i sistema lesokhozyaystvennykh meropriyatiy po likvidatsii ikh posledstviy. Yoshkar-Ola: PGTU.

13) Kupriyanov, N.V. (1994). Lesa i lesnoe khozyaystvo Nizhegorodskoy oblasti. Nizhny Novgorod: Volga-Vyatka Book Publishers.

14) Merrill R. Kaufmann, (2005). Restoration of ponderosa pine forests in the interior western U.S. after logging, grazing, and fire suppression. U Restoration of boreal and temperate forests. (str. 481-500). Washington: CRC Press.

15) Ornatskiy, A.N. (2014). Pozhary i ekologicheskaya bezopasnost lesov na primere Privolzhskogo Federalnogo okruga. Vestnik of Nizhny Novgorod State Agricultural Academy, 4, 207-219.

16) Perkins, J.L. (2015). Fire enhances whitebark pine seedling establishment, survival, and growth. Fire Ecology, 11(2), 84-99. doi:10.4996/fireecology. 1102084

17) Sannikov, S.N. (2009). Evolyutsionnye aspekty piroekologii svetlokhvoynykh vidov. Lesovedenie, 3, 3-10.

18) Sannikov, S.N. (2014). Ekologicheskie katastrofy i mikroevolyutsiya populyatsiy. Eko-potential, 6(2), 42-54.

19) Shirnin, A.Y. (2014). Machine for combined timber skidding based forwarder and an analysis of its performance. Proceedings of the Volga State University of Technology. Series: Technological, 2, 218-223.

20) Shirnin, A.Y. (2016). Comparison of systems of cars for extreme conditions logging. Journal of Applied Engineering Science, 14(2), 206-212. doi:10.5937/jaes14-8980

21) Shirnin, A.Y. (2014). Energy efficient machine for the combined logging in extreme conditions logging. Modern problems of science and education, 6, Preuzeto sa http://www.science-education.ru/120-16640 2015 Dec 26.

22) Shirnin, A.Y. (2014). Ways of solution of timber harvesting problems in extreme conditions. Vestnik of Volga State University of Technology. Series: Forest. Ecology. Nature management, 2, 46-54.

23) Shirnin, A.Y. (2013). Modeling of tree fire blanks defeat chainsaw and technological 
module with winch. Modern problems of science and education, 6, Preuzeto sa URL: www.science-education.ru/113-10927

24) Shirnin, Y.A. (2014). Razrabotka parametrov oborudovaniya i tekhnologii dlya ekstremalnykh usloviy lesozagotovok. Yoshkar-Ola: VSUT.

25) Shirnin, Y.A. (2010). Combined skidding of wood with replacement technological units. Forestry journal, 2, 67-72.

26) Shirnin, Y.A. (2008). Technique of the substantiation of operating modes for technological modules at combined wood hauling. Vestnik of Volga State University of Technology. Series: Forest. Ecology. Nature management, 2, 51-59.

27) Trestsov, B.I. (1976). Lesa Mariyskoy ASSR i likvidatsiya lesnykh pozharov. U Problemy likvidatsii posledstviy lesnykh pozharov 1972 g. v Mariys- koy ASSR. (str. 5-14). Yoshkar-Ola: MarPI.

28) Preuzeto sa http://dop1952.ru/statues-statue_id-1.html 2015 Jun 25.

29) Vorontsov, A.I. (1976). Prognoz razmnozheniya entomvrediteley $v$ gorelnikakh i metody borby $\mathrm{S}$ nimi. U Problemy likvidatsii posledstviy lesnykh pozharov $1972 \mathrm{~g}$. v Mariyskoy ASSR. (str. 94-101). Yoshkar-Ola: MarPI.

30) Yashnov L.I., (1930). Obzor issledovaniy lesovozobnovleniya na garyakh Maroblasti provedennykh kafedroy obshchego lesovodstva Kazanskogo instituta selskogo khozyaystva i lesovodstva. Proceedings of the Kazan Institute of Agriculture and Forestry, 18-26.

Paper sent to revision: 21.11.2015.

Paper ready for publication: 11.12.2015. 